\title{
Relationship between Brazilian Thoroughbred race horses performance and lay-up period after osseous thoracic limb diseases
}

\author{
Relação entre o desempenho e período de recuperação após enfermidades ósseas do membro \\ torácico distal de cavalos Puro Sangue Inglês
}

\author{
Marsel de Carvalho Pereira ${ }^{I}$ Carlos Augusto Araújo Valadão II Antonio Sergio Ferraudo ${ }^{\text {III }}$ \\ Carolina Berkman ${ }^{\mathrm{IV}}$ Guilherme de Camargo Ferraz ${ }^{\mathrm{IV}}$ Antonio Queiroz-Neto ${ }^{\mathrm{IV} *}$
}

\begin{abstract}
It is well established in the literature that musculoskeletal injuries are important compromising agents in the performance of Thoroughbred horses. In Brazil, there are no studies on the interrelation between lay-up period post-injury and retirement of racehorses due to musculoskeletal injures. The aim of this study is to determine the relationship between rehabilitation times of track injures and variables of prior race performance and later return to competitions. The radiographic reports and athletic history of 416 thoroughbreds during the period between 2003 and 2006 were examined; they were selected based on continued presentations after injury diagnosis. The temporal variables (post-injury rehabilitation time) and performance variables (race score before and after injury) were evaluated by multivariate correspondence analysis of the data and represented in perceptual maps. Correspondence was observed between most of the animals that had a short lay-up post-injury and variables that denote decline in subsequent performance. Considering the integrity of the bone healing process as crucial for the horse to be able to handle later training routines and competitions, shortening this period could lead to an imbalance of the bone repair metabolism, thus resulting in performance decline and compromise of the horse athletic career.
\end{abstract}

Key words: horse, race classification, rehabilitation, multiple correspondence analyses.

\section{RESUMO}

Está bem estabelecido na literatura que as lesões músculo-esqueléticas são importantes agentes comprometedores do desempenho em cavalos PSI de corrida. No Brasil, não existem estudos sobre a relação entre o período de reabilitação póslesional e o afastamento de cavalos de corridas devido a lesões músculo-esqueléticas. O objetivo deste estudo foi determinar se existe relação entre o tempo de reabilitação de injúrias adquiridas na pista e os resultados obtidos em corridas, antes e depois de retornar às competições. Entre 2003-2006, foram examinados os relatórios radiológicos e história atlética de 416 PSI, selecionados com base em apresentações continuadas após o diagnóstico das lesões. As variáveis temporais (tempo de reabilitação pós-lesão$R T)$ e variáveis de desempenho (pontuação corrida antes e depois da injúria-SB/SA) foram avaliadas por análise de correspondência multivariada dos dados e representado em mapas de percepção. Correspondência foi observada entre a maioria dos animais que tiveram uma recuperação pós-lesão curta e variáveis que denotam o declínio no desempenho subsequente. Considerando a integridade do processo de cicatrização óssea como crucial para o cavalo a ser capaz de lidar com rotinas de treinamento e competições, o encurtamento deste período poderia levar a um desequilíbrio no metabolismo de reparação óssea, resultando em comprometimento do desempenho e da carreira atlética.

Palavras-chave: cavalo, rabilitação, análise de correspondências múltiplas.

\section{INTRODUCTION}

High performance athlete horses routinely coexist with lameness, and musculoskeletal injuries are consensually indicated as the principal reasons for Thoroughbred horse performance loss during training and competitions (VERHEYEN \& WOOD, 2004), which represents millions of dollars annually to the horse industry (DABAREINER,

'Programa de Pós-graduação em Biociência, Universidade de Cuiabá (UNIC), Cuiabá, MT, Brasil.

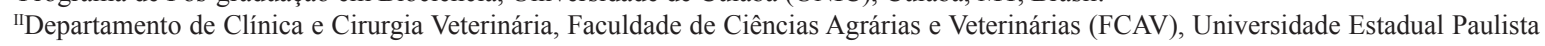
(UNESP), Jaboticabal, SP, Brasil.

IIIDepartamento de Ciências Exatas, FCAV, UNESP, Jaboticabal, SP, Brasil.

${ }^{\mathrm{IV}}$ Departamento de Morfologia e Fisiologia Animal, FCAV, UNESP, 14884-900, Jaboticabal, SP, Brasil. E-mail: aqueiroz@fcav.unesp.br. *Autor para correspondência. 
2009). In this context, some of the several factors associated with the musculoskeletal injuries are gender and age (MEARA et al., 2010), exercise overload (VERHEYEN \& WOOD, 2004), angular limb deformities (AXELSSON et al., 2001), horse handicap and racing class (MOHAMMED et al., 1991), as well as pre existing injuries (HILL et al., 2001), racing direction, track surface and weather conditions (OIKAWA \& KUSUNOSE, 2005).

Two important questions must be considered to warrant a good performance after a rehabilitation period: the length of the rehabilitation period and exercise intensity during this time. It has been observed that an inappropriate rehabilitation period (lay-up) can be deleterious to recovery processes (PARKIN, 2008).

Despite the direct relation between the lay-up period after injuries and a subsequent good performance, there are still contradictory opinions on this subject. While some authors suggest that long periods of rest are beneficial, mainly with respect to the extension of athletic career (BAILEY et al., 1999), others report greater risk of injuries among those horses with a few starts during the year (MOHAMMED \& HILL, 1991) that could also be due to long lay-up periods.

The intent of this paper was to show the influence of the lay-up period on athletic performance of Thoroughbred horses by evaluating variables associated with racing performance prior to and after radiological reports of a group of osseous thoracic limb injuries.

\section{MATERIALS AND METHODS}

The databank of the Department of Radiology, Octavio Dupont Veterinary Hospital in the Brazilian Jockey Club/Rio de Janeiro (HVOD$\mathrm{JCB} / \mathrm{RJ}$ ) was examined to search for appendicular lesion reports during the years from 2003 to 2006. The radiographic reports of 416 Thoroughbred race horses were selected. All horses were completely recovered from a single appendicular lesion after a lay-up period. Their names were crossed with the genealogical registry of the Brazilian Stud Book to obtain the history of their athletic endeavors prior to and after the radiographic reports (lay-up) from each year of study. The horses were distributed in four groups according to the year of evaluation (2003, G1, $\mathrm{n}=133 ; 2004, \mathrm{G} 2, \mathrm{n}=110 ; 2005, \mathrm{G} 3, \mathrm{n}=91$ and 2006, $\mathrm{G} 4, \mathrm{n}=82$ ) and were independently analyzed. There were no repetitions of horses through the years.
Considering the multiplicity of related lesions, we used only the radiograph reports that were distributed in three categories of lesions, as follows: periostitis of the third metacarpal bone (46\%), periostitis of metacarpo-phalangeal joint $(18 \%)$ and mild carpal fractures $(25 \%)$.

The variables proposed and their respective categories used to determine the correlation between lay-up period and athletic endeavors were the length of rehabilitation time after radiographically reported injury, as follows: Short - $\mathrm{RT}_{\mathrm{s}}$ - (when less than 1 month); Medium - $\mathrm{RT}_{\mathrm{m}}$ - (when more than one and less than two months); Long - $\mathrm{RT}_{1}$ - (when three months and longer) and the score obtained during the athletic career (Before - SB) and (After - SA) injury and lay-up. The score classification was achieved by attributing points according to the position at the finish of each race and category of trials (Table 1), varying from 0 ( $5^{\text {th }}$ place in low classified trials $)$ to 10 ( $1^{\text {st }}$ place in high classified trials). Scores, 1 to 5 were classified as low (1) and could be attributed to the period before $\left(\mathrm{SB}_{1}\right)$ and after $\left(\mathrm{SA}_{1}\right)$ injury layup. Scores from 6 to 10 were considered regular $(\mathrm{r})$, before $\left(\mathrm{SB}_{\mathrm{r}}\right)$ and after $\left(\mathrm{SA}_{\mathrm{r}}\right)$. Scores from 11 to 20 were good $(\mathrm{g})$, before $\left(\mathrm{SB}_{\mathrm{g}}\right)$ and after $\left(\mathrm{SA}_{\mathrm{g}}\right)$, and scores higher than 20 , excellent $(\mathrm{e})$, before $\left(\mathrm{SB}_{\mathrm{e}}\right)$ and after $\left(\mathrm{SA}_{\mathrm{e}}\right)$. The group races (GI, GII and GIII), as well as the categories L (Listed); CL (Classic); GP (Gran Prix); PE (Especial); PO (Ordinary) are routinely determined by the Brazilian Jockey Club and can be found in the site (http://www.jcbinforma. com.br/)

Exploratory Multivariate Correspondence Analysis was used to find associations between categories of temporal variables $\left(\mathrm{RT}_{\mathrm{s}}, \mathrm{RT}_{\mathrm{m}}\right.$ and

Table 1 - Correlation points between race categories and final starts classification of Thoroughbred horses during 2003-2006 athletic career evaluation.

\begin{tabular}{|c|c|c|c|c|c|c|}
\hline $\begin{array}{l}\text { Final race } \\
\text { classification }\end{array}$ & GI & GII & GIII & $\mathrm{L}$ & CL, GP e PE & PO \\
\hline $1^{\mathrm{st}}$ & 10 & 8 & 6 & 5 & 4 & 3 \\
\hline $2^{\underline{\text { nd }}}$ & 8 & 6 & 5 & 4 & 3 & 2 \\
\hline $3^{\text {rd }}$ & 6 & 5 & 4 & 3 & 2 & 1 \\
\hline $4^{\text {th }}$ & 5 & 4 & 3 & 2 & 1 & 0 \\
\hline $5^{\text {th }}$ & 4 & 3 & 2 & 1 & 0 & 0 \\
\hline
\end{tabular}

*Race categories: GI, GII, GIII (Group - in order of importance); L (Listed); CL (Classic); GP (Gran Prix); PE (Especial); PO (Ordinary). 
$\left.\mathrm{RT}_{1}\right)$ and performance $\left(\mathrm{SB}_{1}\right.$ and $\mathrm{SA}_{1} ; \mathrm{SB}_{\mathrm{r}}$ and $\mathrm{SA}_{\mathrm{r}}$; $\mathrm{SB}_{\mathrm{g}}$ and $\mathrm{SA} ; \mathrm{SB}_{\mathrm{e}}$ and $\mathrm{SA}_{\mathrm{e}}$ ). The animals selected were grouped annually (2003 to 2006), divided by sex (males and females) and represented spatially by perceptual maps. The proximity between the constituent variables of the perceptual maps, as well the arrangement in the map itself, demonstrates similarities and dissimilarities between the variables.

\section{RESULTS}

The 416 horses selected were distributed as follows: 133 animals in 2003 - 96 males (M) and 37 females (F), 110 in 2004 (84 M and 26 F), 91 in 2005 (71 $\mathrm{M}$ and $20 \mathrm{~F}$ ) and 82 in 2006 (54 M and $28 \mathrm{~F}$ ).

The evaluations for all four years are represented by tree perceptual maps. The first and second (Figure 1A and 1B), represent, respectively, the correspondence among variables of lay-up period and athletic endeavors of female and male horses during the 2003 to 2006 years. The third map (Figure 2) shows both females and males as one population and the evaluation of those correspondence variables already cited before.

A parallel evaluation of female and male behavior during all four years of study (Figure 1A and 1B) shows an improvement in performance in correspondence with a long lay-up period $\left(\mathrm{RT}_{1}\right)$ in both perceptual maps. The females had low performance score before injury $\left(\mathrm{SB}_{1}\right)$ and good performance score after injury $\left(\mathrm{SA}_{\mathrm{g}}\right)$. While males showed a performance improvement that could be represented by a low performance score before injury $\left(\mathrm{SB}_{1}\right)$ followed by an excellent performance score after injury $\left(\mathrm{SA}_{\mathrm{e}}\right)$. For the medium lay-up period $\left(\mathrm{RT}_{\mathrm{m}}\right)$, female performance remained unchanged $\left(\mathrm{SB}_{\mathrm{e}}-\mathrm{Sa}_{\mathrm{e}}\right)$. On the other hand,

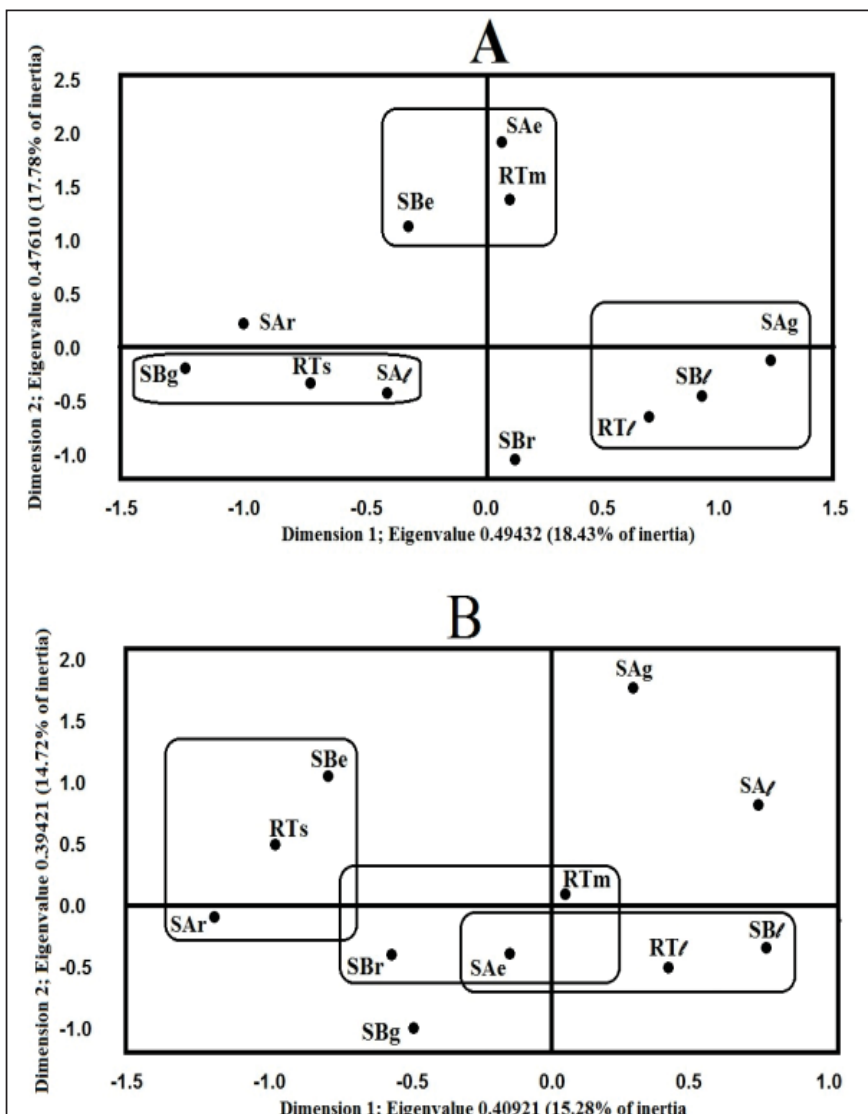

Figure 1 - (A) Perceptual map of females (B) Perceptual map of males. Both for multivariate correspondence analysis of the evaluation of temporal and performance variables during the years 20032006. $\mathrm{RT}_{1}$ - long rehabilitation time after injury; $\mathrm{RT}_{\mathrm{m}}-$ medium rehabilitation time after injury; $\mathrm{RT}_{\mathrm{s}}$ - short rehabilitation time after injury; $\mathrm{SB}_{1}-$ low score before injury; $\mathrm{SB}_{\mathrm{r}}-$ regular score before injury; $\mathrm{SB}_{\mathrm{g}}-$ good score before injury; $\mathrm{SB}_{\mathrm{e}}-$ excellent score before injury; $\mathrm{SA}_{1}-$ low score after injury; $\mathrm{SA}_{\mathrm{r}}-$ regular score after injury; $\mathrm{SA}_{\mathrm{g}}$ - good score after injury; $\mathrm{SA}_{\mathrm{e}}$ - excellent score after injury. 


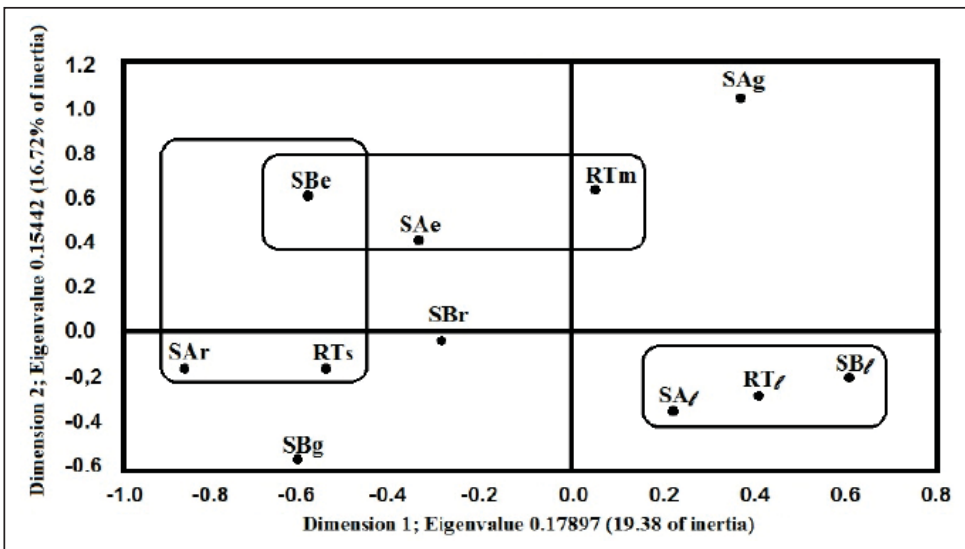

Figure 2 - Perceptual map of the union of multivariate correspondence analysis between females and males in the analysis of temporal and performance variables during the years 2003-2006. $\mathrm{RT}_{1}$ - long rehabilitation time after injury; $\mathrm{RT}_{\mathrm{m}}$ - medium rehabilitation time after injury; $\mathrm{RT}_{\mathrm{s}}$ - short rehabilitation time after injury; $\mathrm{SB}_{1}-$ low score before injury; $\mathrm{SB}_{\mathrm{r}}-$ regular score before injury; $\mathrm{SB}_{\mathrm{g}}$ - good score after injury; $\mathrm{SB}_{\mathrm{e}}-$ excellent score before injury; $\mathrm{SA}_{\mathrm{l}}$ - low score after injury; $\mathrm{SA}_{\mathrm{r}}$ - regular score after injury; $\mathrm{SA}_{g}$ - good score after injury; $\mathrm{SA}_{\mathrm{e}}$ - excellent score after injury.

male performance improvement was represented by a regular score before injury $\left(\mathrm{SB}_{\mathrm{r}}\right)$ and excellent score after injury $\left(\mathrm{SA}_{\mathrm{e}}\right)$. When the short lay-up period was assessed, both females and males showed a decline in performance correspondence: females $\left(\mathrm{SB}_{\mathrm{g}}-\mathrm{SA}_{\mathrm{l}}\right)$ and males $\left(\mathrm{SB}_{\mathrm{e}}-\mathrm{SA}_{\mathrm{r}}\right)$.

When females and males were grouped together and evaluated as a unique population (Figure 2), performance correspondence was maintained for long $\left(\mathrm{RT}_{1}: \mathrm{SB}_{1}-\mathrm{SA}_{1}\right)$ and medium $\left(\mathrm{RT}_{\mathrm{m}}: \mathrm{SB}_{\mathrm{e}}-\mathrm{SA}_{\mathrm{e}}\right)$ lay-up periods. However, for the short lay-up period $\left(\mathrm{RT}_{\mathrm{s}}\right)$ we observed a worsening of the performance variables $\left(\mathrm{SB}_{\mathrm{e}}-\mathrm{SA}_{\mathrm{r}}\right)$.

\section{DISCUSSION}

Musculoskeletal injuries have enormous adverse effects on the equestrian industry worldwide, especially for activities involving Thoroughbred horses. Some highly prevalent injuries require weeks or even months for recovery (STOVER, 2003). In this context, the time interval between injury diagnosis and return to competitions (lay-up) is of utmost importance for the athletic horse to regain its competitive potential and influences directly the length of its athletic career.

The influence that lay-up period length (1 month -short; 2 months-medium, and $\geq 3$ months -long) after injury had on the athletic performance of 416 horses was evaluated in the present study. On the other hand, GOMES \& ALVARENGA (1998) and SCHINABEL et al. (2006) assessed rehabilitation time following arthroscopic surgery using the number of days until the first race without a temporal scale of categories. Regarding performance evaluation, GOMES \& ALVARENGA (1998) determined only the percentage of classifications and total number of previous and later races, and did not make clear the categorization of the type of race on which the evaluation was based. The categorization of races before and after the layup period, as done in the present work, is extremely important to assess performance improvement over the rehabilitation period.

Although rare, the use of multivariate statistical techniques in veterinary medicine allows the study of the interdependence between the variables of each horse, making it possible to raise specific and accurate questions of considerable complexity, in a set of data, turning m-dimensional information into tri or bi-dimensional (MANLY, 2008; PEREIRA et al., 2012). Multivariate correspondence analysis using the techniques of perceptual and intuitive representations (HAIR, 1995) was extremely important to show the relative similarities or preferences in relation to categories of variables studied. Based on the categories of variables to be evaluated (binary matrix of individuals/criteria), crossings were made between line and column categories of the matrix, and, consecutively, the correspondences between the categories of variables proposed were represented spatially by perceptual maps. Therefore, the total inertias represented by the perceptual maps guarantee that the axes/components/dimensions display relevant information to the understanding of the totality of data. 
According to CARRIER et al. (1998) periods of athletic inactivity longer than 60 days influence directly the severity of possible future lesions and increase the probability of musculoskeletal injury recurrence when the animals return to races.

The present study showed that all of correspondence relations between the categories of temporal variables and performance indicated performance decline for horses that remained inactive for a short lay-up period $\left(\mathrm{RT}_{\mathrm{s}}\right)$ after a radiographically diagnosed injury (Figures 1A, 1B and 2). Such evidence contrasts with the results of GOMES \& ALVARENGA (1998) who showed that even with a mean of 161 lay-up days (considered extensive in the present study), later athletic performance of the evaluated horses was inferior to previous performance. Similar results were reported by SCHINABEL et al. (2006) who found that even with a mean of 368 rehabilitation days, the majority of the evaluated animals did not show improvement in their later performances. One important reason for the discrepancy in the results could have been that the above cited authors evaluated the recovery from arthroscopic removal of fracture fragments whose challenge was perhaps greater than that faced by the animals of the present study. In fact, it should be expected that a short lay-up period results on a deficiency to regain athletic performance as previously presented. It is important to keep in mind that lay-up period must not be treated as an independent variable. The extension and intensity of the athletic career, the aim of the lay-up itself (injury or just rest) and the intensity of training schedule after lay-up must be considered as intrinsic characteristics that influence the final outcome of the athletic career. For the long lay-up period $\left(\mathrm{RT}_{1}-\geq 3\right.$ months), both females (Figure 1A) and males (Figure $1 \mathrm{~B})$, when observed individually, improved athletic performance variables $\left(\mathrm{SB}_{1}\right.$ to $\left.\mathrm{SA}_{\mathrm{g}}\right)$ and $\left(\mathrm{SB}_{1}\right.$ to $\left.\mathrm{SA}_{\mathrm{e}}\right)$, respectively. However, when studied as one, previous and later athletic performance did not show any differences (Figure 2). Such results are not supported by several authors (STOVER, 2003; MOHAMMED et al., 1991). There is almost a consensus on how threatening a long lay-up period can be to the horse athletic career. In fact, we share such point of view. But whatever has been the cause of the temporary retiring of the races or how long this period was, the crucial matter to be discussed is the training time and intensity that the horses should undergo before re-starting on the race tracks. However, the present study did not take into consideration the training methodology preceding the return to competitions. In this context, it is impossible to be certain how much the training schedules affected the bone structure recovery. Additionally, a possible explanation for this finding would be the greater parsimony of the trainers while training animals that underwent longer recovery period. Anyway, the results expand upon our growing body of evidence on this subject.

After a bone injury and its radiographic identification, there is an active remodeling process balancing the reabsorption and formation of bone. When this equilibrium is not reached due to the short period of rehabilitation after the injury, cellular events follow that result in a process of greater bone reabsorption than formation, leading to bone loss (HUNTER \& SAMBROOK, 2000). On the other hand, when the period of rehabilitation is very long ( $\geq 60$ days) (CARRIER et al., 1998; PARKIN, 2008) inactivity can result in bone disuse atrophy. Such loss is due to the fact that bone tissue possesses a metabolism and maintenance that are energetically expensive, causing consequent greater reabsorption (STOVER, 2003). Contradictory to the above results, HERNANDEZ et al. (2001) observed that horses with more than 32 days since its last race were 2.5 times more prone to musculoskeletal injuries during a race, when compared to those with less than 14 days since the last race. Such findings are in contrast to those of RIGGS (2002) who reported that three months is the ideal time to return to athletic activity, coinciding with the end of the bone remodeling process; in case this period is ignored, the framework is less apt to meet the demands of training.

It is well known that there is a powerful economic incentive to maintain horses in training and racing. Such "incentive" becomes a threat when injuries arise and the urgency for athletic results (earnings) knock at the door. Despite all knowledge about the race structure and equine physiology, injuries still happen and will be happening, and the difference between failure and success could be how we face the challenge and how we prepare the athlete to an even greater challenge: the re-start.

To prevent injuries is the obvious and it has already been practiced day-by-day. But to understand how different kinds of injuries affect each organism at different stages of physical conditioning is the real challenge. Considering the variables that affect the recovery of injuries caused by the races, to correlate bone metabolism with different periods of rehabilitation is of crucial importance in the modeling of clinical protocols, thus, not interfering negatively with wound-healing and, consequently, optimizing later performance. 
Regarding to the osseous thoracic limb diseases studied in the present work, we showed that all correspondence relations between the categories of temporal variables and performance indicated a decline in performance for horses that remained out of the races for a short lay-up period after radiographically diagnosed injury. For a long lay-up period, both females and males improved performance when observed individually.

\section{REFERENCES}

AXELSSON, M. et al. Risk factors associated with hind limb lameness and degenerative joint disease in the distal tarsus of Icelandic horses. Equine Veterinary Journal, v.33, n.1, p.8490, 2001. Available from: <http://onlinelibrary.wiley.com/ doi/10.2746/042516401776767502/pdf>. Accessed: Nov. 19, 2008. doi: $10.2746 / 042516401776767502$.

BAILEY, C.J. et al. Factors associated with time until first race and career duration for Thoroughbred racehorses. American Journal of Veterinary Research, v.60, n.10, p.1196-200, 1999. Available from $<$ http://www.ncbi.nlm.nih.gov/pubmed/10791929>. Accessed: Jan. $1,2009$.

CARRIER, T.K. et al. Association between long periods without high-speed workouts and risk of complete humeral or pelvic fracture in thoroughbred racehorses: 54 cases (1991-1994). Journal of the American Veterinary Medical Association, v.212, n.10, p.1582-1587, 1998. Available from: <http://www.ncbi.nlm. nih.gov/pubmed/9604029>. Accessed: Nov.19, 2008.

DABAREINER, R.M. Musculoskeletal injuries in the western performance horse. In: ROBINSON N.E.; SPRAYBERRY K.A. Current therapy in equine medicine. 6.ed. London: Saunders, 2009. Chapt.109, p.492-494

GOMES, T.L.S.; ALVARENGA, J. Evaluation of athletic activity after carpic arthroscopy in fracture of carpic-radial bone of thoroughbred. Brazilian Journal of Veterinary Research and Animal Science, v.35, n.2, p.88-91, 1998. Available from: $<\mathrm{http}: / /$ www.scielo.br/pdf/bjvras/v35n2/35n2a08.pdf $>$. Accessed: Nov. 19, 2008. doi: 10.1590/S1413-95961998000200008.

HAIR, J.F. Group analysis. In: HAIR, J.F. et al. Multivariate data analysis. 4.ed. Upper Saddle River, New Jersey: PrenticeHall, 1995. p.381-405.

HERNANDEZ, J. et al. Race start characteristics and risk of catastrophic musculoskeletal injury in Thoroughbred racehorses. Journal of the American Veterinary Medical Association, v.218, n.1, p.83-86, 2001. Available from: $<$ http://avmajournals. avma.org/doi/abs/10.2460/javma.2001.218.83>. Accessed: Nov. 19, 2008. doi: 10.2460/javma.2001.218.83.

HILL, A.E. et al. Risk factors for and outcomes of noncatastrophic suspensory apparatus injury in Thoroughbred racehorses. Journal of the American Veterinary Medical Association. v.218, n.7, p.1136-1144, 2001. Available from: <http://avmajournals.avma. org/doi/abs/10.2460/javma.2001.218.1136? journalCode=javma $>$. Accessed: Nov. 19, 2008. doi: 10.2460/javma.2001.218.1136.

HUNTER, D.J.; SAMBROOK, P.N. Bone loss: epidemiology of bone loss. Arthritis Research, v.2, n.6, p.441-445, 2000.
Available from: <http://www.ncbi.nlm.nih.gov/pmc/articles/ PMC128872/>. Accessed: Jan. 20, 2009. doi: 10.1186/ar125.

MANLY B.F.J. Métodos estatísticos multivariados: uma introdução. 3.ed. Porto Alegre: Bookman, 2008. 229p.

MEARA, B.O. et al. An investigation of the relationship between race performance and superficial digital flexor tendonitis in the Thoroughbred racehorse. Equine Veterinary Journal, v.42, n.4, p.322-326, 2010. Available from: $<$ http://onlinelibrary.wiley.com/ doi/10.1111/j.2042-3306.2009.00021.x/abstract;jsessionid=60A9 0BBB1ED6A8EA2B634F438F3662F9.d03t01>. Accessed: Apr. 20, 2010. doi: 10.1111/j.2042-3306.2009.00021.x.

MOHAMMED, H.O. et al. Risk factors associated with injuries in Thoroughbred horses. Equine Veterinary Journal, v.23, n.6, p.445-448, 1991. Available from: <http://www.ncbi.nlm.nih.gov/ pubmed/1778162>. Accessed: Apr. 20, 2009.

OIKAWA, M.; KUSUNOSE, R. Fractures sustained by racehorses in Japan during flat racing with special reference to track condition and racing time. Veterinary Journal, v.170, n.3, p.369-374, 2005. Available from: <http://www.deepdyve.com/lp/elsevier/ fractures-sustained-by-racehorses-in-japan-during-flat-racingwith-JbGywtTMwh>. Accessed: Apr. 20, 2009. doi: 10.1016/j. tvj1.2004.08.004.

PARKIN, T.D.H. Epidemiology of racetrack injuries in racehorses. Veterinary Clinics of North America. Equine Practice, v.24, n.1, p.1-19, 2008. Available from: $<$ http://ac.elscdn.com/S0749073907000697/1-s2.0-S0749073907000697-main. pdf? tid $=8 \mathrm{~b} 8 \mathrm{f} 7 \mathrm{da} 8-355 \mathrm{f}-11 \mathrm{e} 2-8 \mathrm{faf}-00000 \mathrm{aab} 0 \mathrm{f} 6 \mathrm{c} \& \mathrm{acdnat}=1353$ 669705_16052c62de9cc48abff257f448670d09>. Accessed: Apr. 20, 2010. doi:10.1016/j.cveq.2007.11.003.

PEREIRA, M.C. et al. Causes of death of Thoroughbred racehorses at Octavio Dupont Veterinary Hospital, Brazilian Jockey Club, Rio de Janeiro. Pesquisa Veterinária Brasileira, v.32, n.3, p.189-193, 2012. Available from: <http://www.scielo. $\mathrm{br} / \mathrm{scielo}$.php? pid=S0100-736X2012000300001\&script $=\mathrm{sci}$ arttext>. Accessed: Aug. 18, 2010. doi: 10.1590/S0100736X2012000300001.

RIGGS, C.M. Fractures: a preventable hazard of racing Thoroughbreds? Veterinary Journal, v.163, n.1, p.19-29, 2002. Available from: <http://www.sciencedirect.com/science/article/pii/ S1090023301906100>. Accessed: Apr. 20, 2010. doi: 10.1053/ tvj1.2001.0610.

SCHINABEL, L.V. et al. Racing performance after arthroscopic removal of apical sesamoid fracture fragments in Thoroughbred horses age $\geq 2$ years: 84 cases (1989-2002). Equine Veterinary Journal, v.38, n.5, p.446-451, 2006. Available from: $<$ http://www. ncbi.nlm.nih.gov/pubmed/16986606>. Accessed: Apr. 20, 2010 doi: $10.2746 / 042516406778400655$.

STOVER, M.S. The epidemiology of Thoroughbred racehorse injuries. Clinical Techniques in Equine Practice, v.2, n.4, p.312-322, 2003. Available from: $<$ http://www.sciencedirect.com/ science/article/pii/S1534751604000083>. Accessed: Nov. 19, 2008. doi: 10.1053/j.ctep.2004.04.003.

VERHEYEN, K.L.P.; WOOD, J.L.N. Descriptive epidemiology of fractures occurring in British Thoroughbred racehorses in training. Equine Veterinary Journal, v.36, n.2, p.167-173, 2004. Available from: $<$ http://www.ncbi.nlm.nih.gov/pubmed/15038441>. Accessed: Dec. 20, 2009. doi: 10.2746/0425164044868684. 